\title{
Transpiration and the Ascent of Water in Trees under Australian Conditions.
}

\author{
BY \\ ALFRED J. EWART, D.Sc., PH.D., F.L.S., \\ Government Botanist and Professor of Botany in Melbourne University; \\ AND \\ BERTHA REES, \\ Government Research Bursar, Melbourne University.
}

With five Figures in the Text.

I $\mathrm{N}$ two previous papers ${ }^{1}$ on the ascent of water in trees, investigations were made in regard to the physics of the ascent of sap, and from the data thus obtained experiments were performed to test whether any of the existing theories afforded a complete explanation of all the phenomena associated with the ascent of sap in tall trees. The net result of the previous. work has been to show that the problem is more a kinetic than a static one, the actual resistance to flow during active transpiration being much greater than might be imagined from purely theoretical considerations. In addition it was shown that no evidence could be obtained of any pressure or suction at a given point sufficient to explain the total ascent in a tall tree during active transpiration, and that in the wood of a tree killed by formalin the sap appeared to turn to the older, still living wood, which normally, owing to its higher resistance and lesser activity, takes little or no part in the ascent of sap. The mere fact that dead wood soon loses its conductivity and cannot retain it permanently under transpiration conditions, even after injection with water, is sufficient to show that in this respect at least the ascent of sap is a vital problem, that is to say, one which cannot at present be wholly explained by reference to known physical and chemical agencies. All the data on which these conclusions were based were, however, obtained in England with English or English-grown trees, and naturally the opportunity of checking all the conditions in Australia, where the tallest trees grow, and where the

1 Phil. Trans. R.S. of London, Series B, vol. cxcviii, I905, p. 4I ; Ibid., vol. cxcix, I908, p. 34I.

[Annals of Botany, Vol. XXIV. No. XCIII. January, I9ro.] 
conditions are in some respects almost unique, and with abundant material close at hand, was of great value. The work was carried out with the aid of a grant by the Royal Society from the Home Government's research fund.

The points of special importance to determine were : the rate of transpiration under Australian conditions, the rate of ascent of sap, more especially in Eucalyptus trees, the length and diameter of the vessels, the condition of the conducting tissue during active transpiration, and the maximal and average resistances to flow in functioning stems. The total resistance to flow naturally will depend on the height of the tree, and the tallest trees known only slightly exceed 300 feet in height. In the previous paper the greatest height given for Eucalyptus amygdalina was 303 feet. I have since found an authentic properly measured record of 330 feet by Mr. Clement Hodgkinson, a former head of the Lands Department, taken nearly half a century ago, and although the tree does not now appear to be in existence, there is no reason to doubt the record. ${ }^{1}$ As regards this genus, Eucalyptus diversicolor of W. Australia appears to come second, and the Eucalyptus microcorys of N.S. Wales third in height, but many species are often found to attain heights of 100 to 200 feet in the heavily timbered districts of Victoria, although the trunks are usually slender as compared with the height. A tree, however, commonly continues to grow in diameter after it has attained its maximal height, and hence in aged specimens the disparity between the diameter and height is reduced. The next tallest tree recorded is presumably the 'Keystone State' Sequoia of Calaveras with 325 feet in height and 45 feet in diameter. The Sequoias appear in general to have bulkier stems for a given height than Eucalyptus, and this, coupled with the slower rate of transpiration, makes up for the comparatively high resistance to flow in their non-vascular wood. In fact, as has already been shown, ${ }^{2}$ the development of wood on a tree is primarily due to the necessity of maintaining a sufficient sectional area of wood containing living cells, and hence capable of active conduction, the purely mechanical functions of the stem being secondary in character; the main stem of a tree which has attained its maximal height will continue to increase in girth and strength even although the upper half may be decreasing in weight.

\section{Transpiration under Australian Conditions.}

In at least one respect the Australian conditions as represented in the Melbourne district are comparatively unique, for at certain times hot dry winds blow from the interior and cause rapid rises of temperature up to $100^{\circ}$

${ }^{1}$ Dr. Howitt, in the Proc. Roy. Soc. of Vict., New Series, vol. iii, I89I, p. I28, gives a measurement of $35^{\circ}$ feet on a fallen Eucalypt, but without details and without mentioning whether the measurement included any portion of the root system.

${ }^{2}$ Phil. Trans. R.S., Series B, vol. cxcviii, I905, p. 69. 
or even $120^{\circ} \mathrm{F}$. The curves appended ${ }^{1}$ (Fig. I) give some idea of the character of these changes, which usually end suddenly when the cool south wind sets in, the temperature often falling a degree a minute for a quarter to half an hour or at a less rate over a somewhat longer period. The rate of evaporation from a free surface of water is exceedingly rapid when the hot dry north wind is blowing from the interior, and since these hot spells often come when the ground is still quite moist, we should expect to find the rate of transpiration extremely high at such times. The hot spell rarely lasts long and is usually followed by a cool change often accompanied by rain.

$\mathrm{F}$

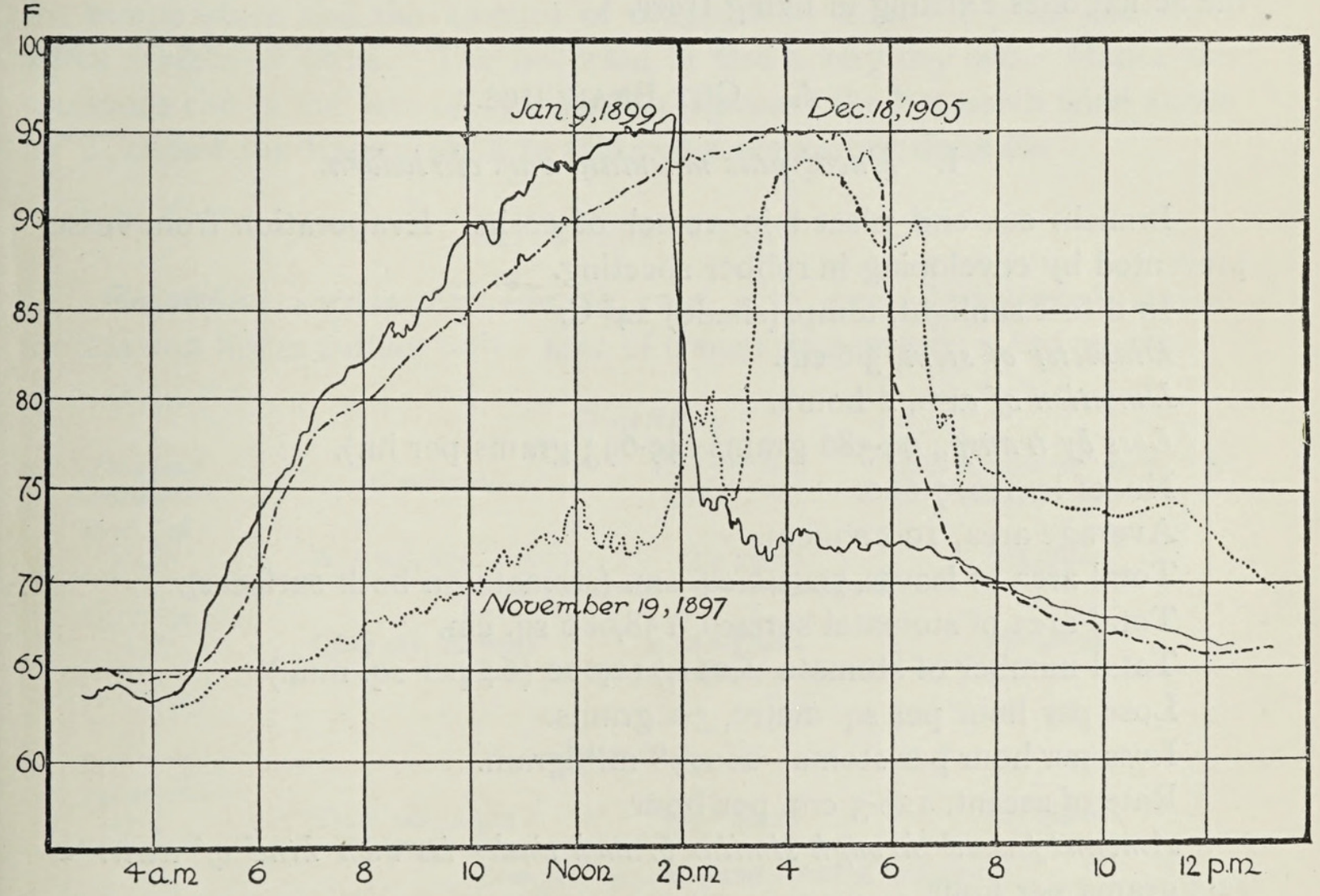

Figl. Thermographs from Melbourne Observatory

The fall of temperature is usually more rapid than the rise, but in the curve for November 19,1897 , the reverse is the case. In neither case does the suddenness of the change appear to operate injuriously upon the vegetation, while its rapidity and irregular occurrence would be sufficient to prevent slowly responding plants specially adapting themselves to it.

Nevertheless a prolonged hot spell results in a regulatory diminution of the rate of transpiration even when the soil is kept moist. Cut branches supplied with water show the same peculiarity, although, as might be expected, they always transpire less actively under otherwise similar conditions than plants rooted in the soil. The amount of water passing

1 Extracted from unpublished Observatory records with Mr. Baracchi's kind consent. 
through a similar branch taken from an equally actively transpiring plant and subjected to its own head of water was also measured, and it will be seen that assuming the flow to be proportional to the head, it would require heads several times the length of the stem to produce the transpiratory rate of flow. As a matter of fact, the head required in a transpiring plant to maintain the transpiration current increases more rapidly than the rate of flow as the velocity of flow increases. If the stems are previously specially prepared and fully saturated, the resistance is of course greatly decreased, but we are concerned not with theoretical conditions, but with the actual ones existing in living trees.

\section{A. Cut Branches.}

I. Eucalyptus maculata var. citriodora.

Branch, cut end placed in vessel of eosin. Evaporation from vessel prevented by enveloping in rubber sheeting.

In direct sunlight, temp. (shade) $24^{\circ} \mathrm{C}$.

Diameter of stem, $3.6 \mathrm{~cm}$.

Duration of exp., 2 hours.

Loss by transp., $99 \cdot 386$ grams (49.693 grams per hr.).

No. of leaves, 7,600 .

Average area, 10.4 sq. $\mathrm{cm}$.

Total area of leaves, 79,040 sq. $\mathrm{cm}$. (stomata on both surfaces).

Total area of stomatal surface, I $58,080 \mathrm{sq} . \mathrm{cm}$.

Total number of stomata, I, OI I, 7 I 2,000 (64 per sq. mm.).

Loss per hour per sq. metre, $3 \cdot 1$ grams.

Loss per hour per stoma, $\cdot 000048$ milligram.

Rate of ascent, $128.5 \mathrm{~cm}$. per hour.

Amount passed through similar branch under its own head of water = 12.5 grams per hour.

Hence head required to maintain transpiratory rate of flow should be not less than seven to eight times the length of the stem.

\section{Nerium Oleander.}

Stem set up as in I. ; shade temp. $30^{\circ} \mathrm{C}$.

Duration of exp., I hour.

No. of leaves, I3I.

Average area, $15.6 \mathrm{sq} . \mathrm{cm}$.

Total area of leaves, $2,0 \mathrm{I}_{3} .6 \mathrm{sq}$. $\mathrm{cm}$. (stomata on both surfaces).

Total area of stomatal surface, $4,087 \cdot 2$ sq. $\mathrm{cm}$.

Loss by transpiration, I6 grams.

Average no. of stomata, $3^{\text {I } 8,801,601}$ ( 78 per sq. mm.). ${ }^{1}$

1 The fact that the stomata are sunk in pits below the surface makes exact counting difficult. 
Loss per hour per sq. metre, 3.9 grams.

Loss per hour per stoma, .00005 milligram.

Rate of ascent, $25.5 \mathrm{~cm}$. per hour.

Amount passed through similar branch under its own head $=0.4$ gram per hour. Hence head of water required to produce transpiratory rate of flow would be at least forty times length of stem.

The observations on rooted plants in pots were prolonged throughout the year, but only those data are given which represent various conditions at the different seasons. The appended curves give the relation between the temperature and the amount of evaporation from the plant and from a free surface of water. The hot wind is also a very dry one. Hence the enormous rise in the rate of evaporation, whereas the hot north wind about $27^{\circ} \mathrm{C}$. causes the transpiration to undergo a regulatory decrease.

\section{B. Trees in Pot.}

Eucalyptus corynocalyx (young tree with oval dorsiventral leaves, stomata on under surface only), area of transpiring surface, 5 , I20 sq. $\mathrm{cm}$.

\section{Winter.}

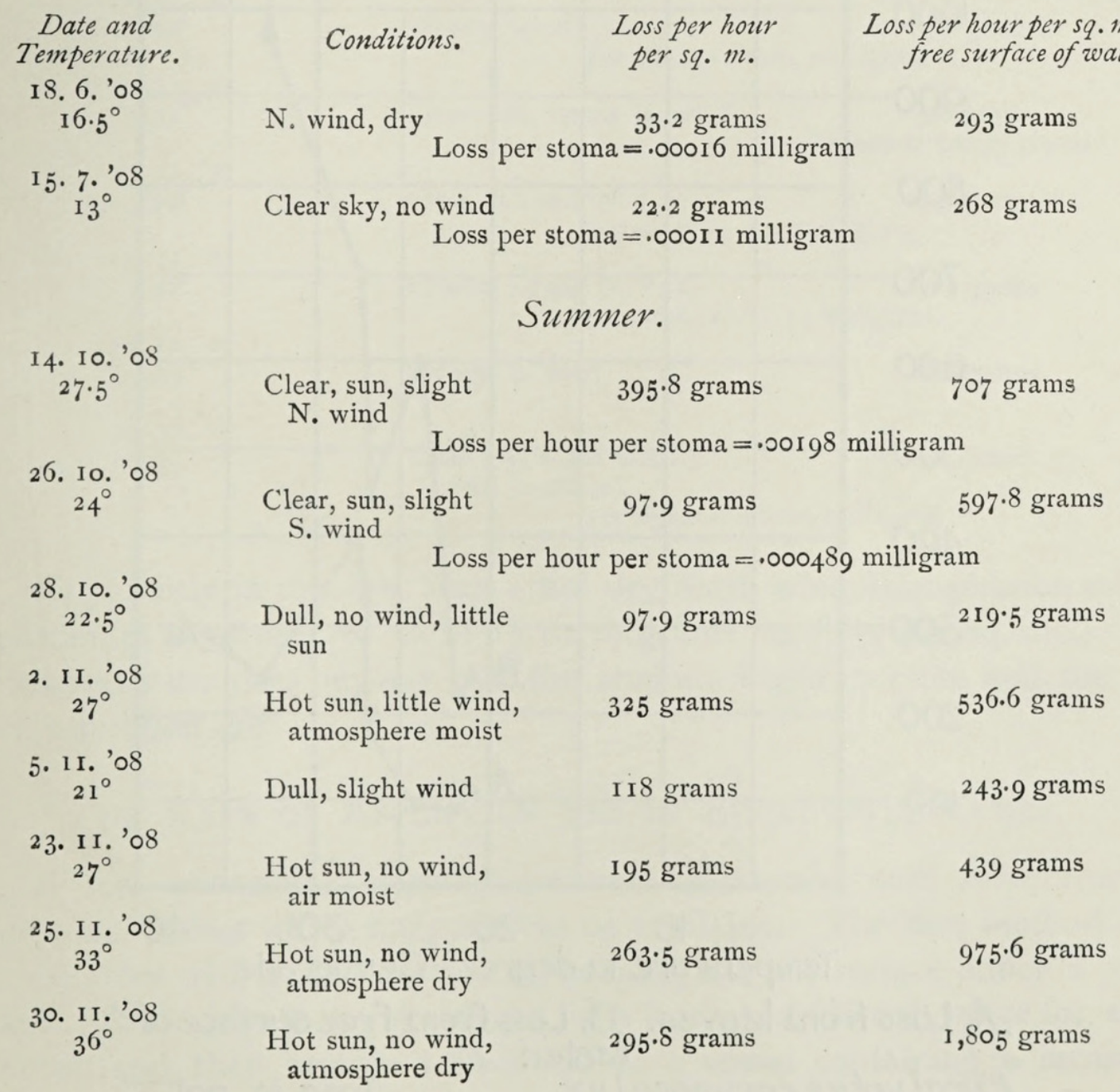


90. Ewart and Rees.-Transpiration and the Ascent of

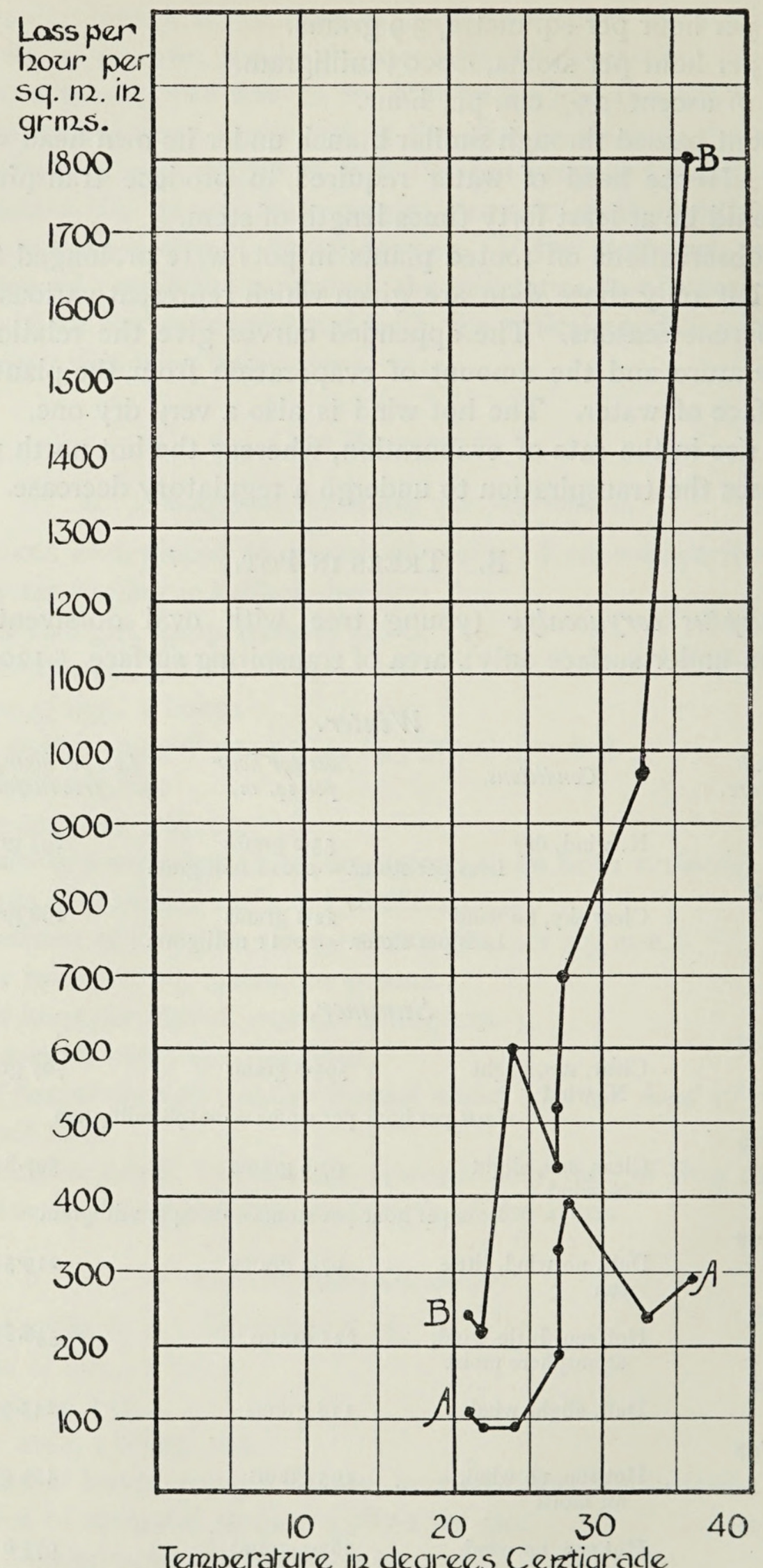

A. Loss from leaves. B. Loss fronz free surface of water:

Eucalyptus corynocalyx.

Tree in pot

Figure 2 


\section{Dracaena Draco.}

Area of stomatal surface $=3 \cdot 2256$ sq. m.

Stomata on both surfaces, most plentiful on upper surface along midrib.

This plant was kept under observation from November 13 to 30 inclusive, excepting 16 th, 17 th, and 24 th. During this period the total loss amounted to $2,754 \cdot 4 \mathrm{I} 2$ grams or an average of $172 \cdot 15$ per day.

The average loss per hour per sq. $\mathrm{m} .=\mathrm{II} \cdot 7$ grams.

Average loss per hour per stoma $=.00078$ milligram.

The following table shows a few of the individual results under as divergent conditions as possible :-

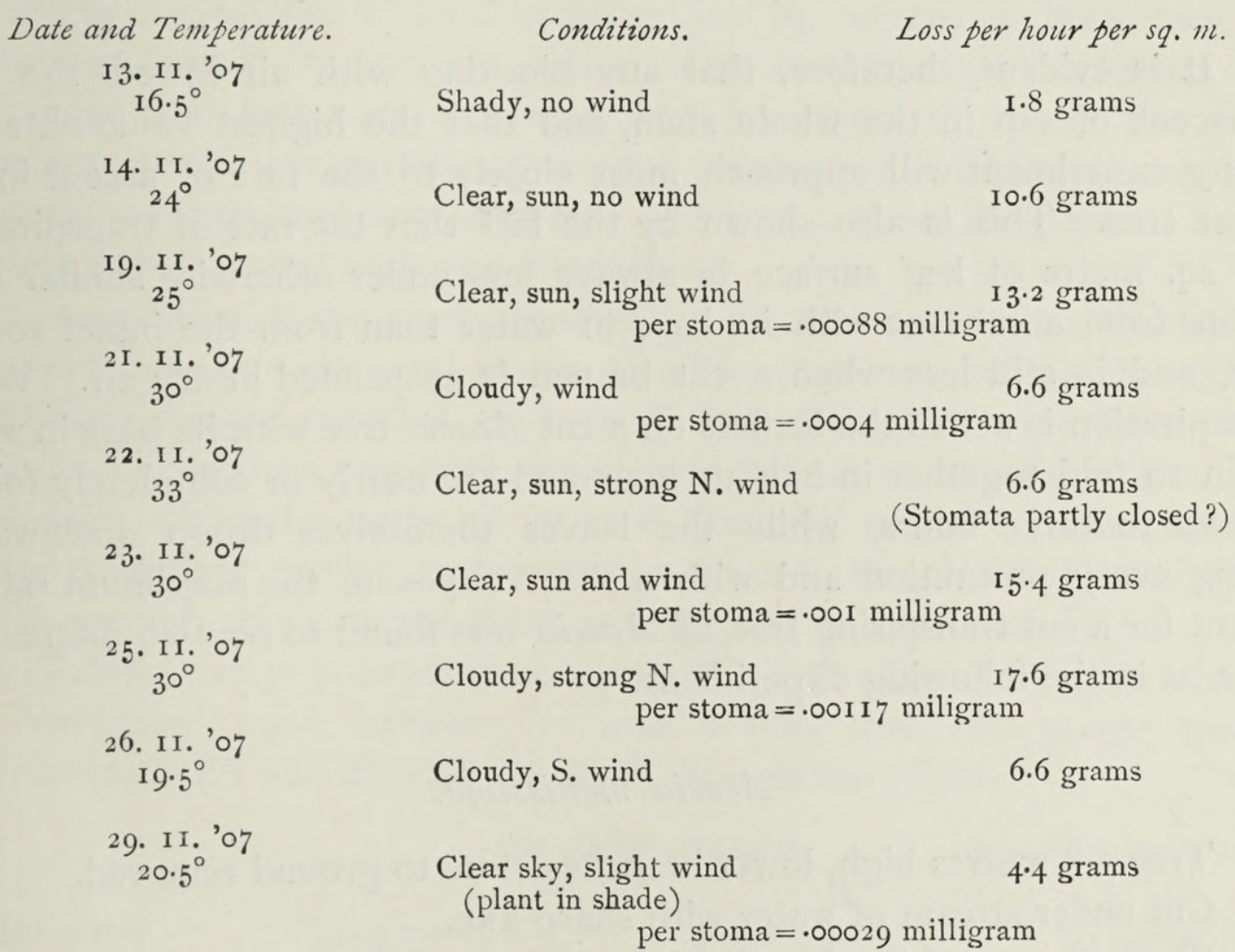

Apparently in this case with a hot dry north wind, transpiration attains a maximum at or near $30^{\circ} \mathrm{C}$. of $\mathrm{I} 7$ to $\mathrm{I} 8$ grams per hour per sq. metre. If the temperature rises beyond this the stomata begin to close and the rate of transpiration falls.

\section{The Rate of Ascent of Sap in Eucalyptus Trees.}

A few orientating experiments were performed with some trees of Acacia mollissima which happened to be available. The best method is to cut the trees with a very sharp axe, keeping the cut surface under a jet of water. The cut end is then placed in a bucket of filtered water for a few minutes, and then rapidly transferred to a vessel containing a measured 
quantity of eosin solution. However carefully the work is done a little air always enters, and by blocking some vessels might cause the liquid to rise more rapidly in the others than it does in the intact tree.

Hence one tree, A, was sawn through with a cut sloping slightly downwards and an inch jet of water assured that no air entered. The sawn end was then cut afresh with a wood chisel under water and trimmed with a sharp razor. The second one, B, was cut with a sharp axe and the cut end exposed to air for thirty seconds, with the following results after each tree had been in eosin for two hours:-

$\begin{array}{cccccc} & \text { Height. } & \text { Rate of ascent of eosin. } & \text { Amount absorbed. } & \text { Temperature. } & \begin{array}{c}\text { Condition. } \\ \text { Tree A }\end{array} \\ 3.65 \text { metres } & 0.97^{2} \text { metre per hour } & 53.8 \text { c.c. per hour } & 18-20^{\circ} \mathrm{C} \text {. } & \text { clear } \\ \text { Tree B } & 5.30 \text { metres } & 0.625 \text { metre per hour } & 98.6 \text { c.c. per hour } & 25-28^{\circ} \mathrm{C} . & \text { slightly cloudy }\end{array}$

It is evident, therefore, that any blocking with air lowers the rate of ascent of sap in the whole stem, and that the highest value obtained in any experiment will approach most closely to the rate of ascent in the intact tree. This is also shown by the fact that the rate of transpiration per sq. metre of leaf surface is always less under otherwise similar conditions from a cut tree with its base in water than from the intact rooted tree, and is still less when a cut branch is suspended in dry air. When transpiration is active the leaflets on a cut Acacia tree with its base in water begin to fold together in half an hour and are nearly or completely folded in two to three hours, while the leaves themselves droop downwards. Using every precaution and with a short exposure the maximum rate of ascent for a cut transpiring tree of Acacia was found to be 2.46 metres per hour, as in the following experiment.

\section{Acacia mollissima.}

Tree 3.8 metres high, lower branches close to ground removed.

Cut under stream of water with sharp axe.

Shade temp. $27^{\circ}$ C. North wind. Time, I2-I p.m. Dec. 7, Ig08.

Eosin ascended 2.46 metres in one hour.

Amount absorbed, $552 \cdot 8$ c.c. per hour.

Leaflets at angle of $30-90^{\circ}$ at commencement.

After half an hour angles began to lessen (deficiency of water?).

At close of experiment distinct signs of drooping in main petioles.

By noting the number of leaves and hence obtaining the transpiration rates per sq. metre from the cut tree and from a separated branch a control of the results can be obtained. Thus in a preliminary two-hour test with a two-year-old shoot of Eucalyptus cormuta 3 metres high, the eosin ascended $60 \mathrm{~cm}$. per hour (shade temp. $19-21^{\circ} \mathrm{C}$.) and the stem absorbed 34 c.c. of water per hour. 
The total number of leaves was $3,3^{2} 3$ with a total area of 7.665 sq. metres. The leaves, being almost all vertical, had stomata on both surfaces and the water absorbed per hour per sq. metre of transpiring surface was therefore 2.22 c.c. A cut branch in air, however, lost 68.5 c.c. per sq. metre per hour, and on examination of the cut stem of the tree it was found that a gummy mass beneath the bark had been carried by the axe over the cut surface, blocking very many of the vessels.

In a similar three-hour experiment with a young tree of Eucalyptus viminalis 4.6 metres high at $23-24^{\circ} \mathrm{C}$. it was found that the eosin rose $93 \mathrm{~cm}$. per hour, and I08.6 c.c. were absorbed, which was only 3.84 c.c. per hour per sq. metre of surface, whereas a cut branch with 805 leaves lost 70.15 c.c. per sq. metre during the first hour of the experiment, and another with 880 leaves lost $60.9 \mathrm{c}$ c. of water per sq. metre per hour during the latter two hours. In this case the blocking was due to the notching of the axe edge and imperfect trimming, but it suffices to show that partial blocking at the cut surface affects the amount absorbed much more than it does the maximal rate of ascent and never causes the latter to become higher than it would be in the intact tree.

In addition, the amount absorbed by a cut tree, as well as that exhaled by a cut branch suspended in air, steadily decreases, even if the external conditions remain constant, or even if they change so as to favour transpiration. Thus in a two-hour experiment with a cut branch of Eucalyptus viminalis, while the temperature rose from $23^{\circ}$ to $26^{\circ} \mathrm{C}$., the amount of water transpired per sq. metre was 40.8 c.c. in the first half-hour, 30 c.c. in the second, 27 c.c. in the third, and 23.5 c.c. in the fourth.

Taking every possible precaution, the following data were obtained in November, I908, between II and 2 p.m. with two young trees of $E$. viminalis (A and $\mathrm{B}$ ) and one of $E$. amygdalina $(\mathrm{C})$ :-

Height of tree

Temperature

Rate of ascent

No. of leaves

Total transpiring surface

Water absorbed per sq.

metre of totalleaf surface

Water transpired per sq. metre from a cut branch suspended in air
Eucalyptus viminalis.

A.

Eucalyptus amygdalina.

B.

3.95 metres

$4.3 \mathrm{metr}$
$26^{\circ} \mathrm{C}$.

I 2.3 metres per hour

7,460

23. I I sq. metres

I 16.6 c.c. per hour

80.95 c.c. per hour $27^{\circ} \mathrm{C}$.

I 0.33 metres per hour

6,200

$20.92 \mathrm{sq}$. metres

I 46.8 c.c. per hour

I I 8.3 c.c. per hour

\section{C.}

$26^{\circ} \mathrm{C}$.

6.5 metres per hour 3,520

28.8 sq. metres?

202 c.c. per hour

I $3 \cdot 6$ c.c. per hour

None of the observations exceeded half an hour's duration, but even then the rate of absorption is much less than the maximal transpiration values for rooted plants of Eucalyptus corynocalyx (300-400 c.c. per hour per sq. metre of transpiring surface). It is evident, therefore, that the sap may rise in Eucalyptus trees ${ }^{1}$ at rates of 30 or 40 feet an hour under

1 Vertical leaves, stomata on both surfaces. 
optimal conditions. In the case of the tree $A$ the area of the stem at the narrowest point below the main branches was $\mathrm{I}, 256 \mathrm{sq}$. $\mathrm{mm}$. and the vessels averaged 29 per sq. mm., so that the total number in the stem at that point was 36,440 . The diameter of the largest was $0.13 \mathrm{~mm}$., and the average diameter $0.083 \mathrm{~mm}$. Hence the total area of cross-section of the vessels would be $\mathrm{I} .93 \mathrm{sq} . \mathrm{cm}$. At a rate of $1,230 \mathrm{~cm}$. per hour the vessels if filled with water would discharge nearly 2,36 I c.c. per hour, whereas the actual amount of water absorbed by the tree was 920 c.c. in twenty minutes. At the base of the stem, however, there were approximately 55,800 vessels with a discharging rate of over 3,600 c.c. per hour. The eosin was fairly evenly distributed throughout the wood from the base to half-way up, and hence not only were the whole of the vessels conducting, but their effective conducting area was little or not at all reduced by the presence of air in them, and the tracheides also may have played some part in the conveyance of water.

Even in the case of a capillary vessel occupied by a continuous column of water and with perfectly smooth internal walls a rate of flow of 10-I 2 metres per hour entails considerable friction and resistance. Thus, in a tube $0.008 \mathrm{~cm}$. diam. and so metres long the frictional resistance would be in the case of water at $20^{\circ} \mathrm{C}$. equivalent to a head of $1,250 \mathrm{~cm}$. of water approximately, or slightly over an atmosphere. Hence in such a case the viscosity factor alone more than doubles the head due to the height of the tree, and to this must be added the resistance due to the transverse partitions, to the irregularities on the internal walls, and to the usual presence of more or less air.

\section{The Diameter and Length of the Vessels in Branches and IN THE MAIN TRUnK.}

The experiments detailed below were performed by driving mercury into the stem under pressure and noting when it escaped from one or more vessels as pieces were cut from the distal end. For the most part each experiment meant the sacrifice of an entire young tree, and the quantity of mercury used was naturally great. For demonstration purposes, however, it is sufficient to use air driven into the stem under pressure from a cylinder of compressed air, and if the wood is fresh and the trunk quite sound this gives as accurate results as the mercury method for determining the length of the longest vessels (Exp. II with Acacia mollissima), since air only escapes freely from vessels uninterrupted by partition walls, even when a pressure of two or three atmospheres is used. The mercury method, however, enables the open vessels to be counted until the number increases considerably, whereas with air, as soon as more than three or four are opened, it is difficult to count the number further back with any accuracy. 
The following observations on Acacia show that a single vessel may run nearly the whole length of the tree, while less than I per cent. ran for one-third, and not more than 5 per cent. for one-fifth the length of the main stem. The vessels in the branches are usually smaller and shorter than in the main axis, and they are more numerous per sq. centimetre in the wood on young stems than in that on older ones. Not only are the longest vessels found in the main axis but they do not appear to run into branches to any extent, and the same applies to the branches themselves; the longest vessels on a main axis do not as a rule run into secondary branches. Hence the number of partition walls in the path of a particular line of sap-flow will always be greater than the number of branchings it passes, and as regards the resistance to flow, this will put a young branch at the top of a tree on a greater equality with the twigs on a basal branch than would otherwise be the case.

Mercury Method.

\section{Acacia mollissima :}

I.

(a)

Full tree

Height $2 \cdot 44 \mathrm{~m}$.

(b)

(c) Branch of same

II. Full tree

Fork (a) Forked trunk

Height $4.5 \mathrm{~m}$.

Mercury method

Fork (b) Height $3.94 \mathrm{~m}$. (Air pressure)

(c) Branch of same Length $94 \mathrm{cms}$.

(d) Branch of same Length $\mathrm{I} \cdot 48 \mathrm{~m}$.

(e) Branch of same Length $\mathrm{I} \cdot 2 \mathrm{I} \mathrm{m}$.

$$
\begin{aligned}
& \text { Age. } \begin{array}{c}
\text { Diameter } \\
\text { at base. }
\end{array} \begin{array}{c}
\text { Position of } \\
\text { longest vessel. }
\end{array} \quad \begin{array}{c}
\text { Length of } \\
\text { longest vessel. }
\end{array} \\
& 6 \text { yrs. } 3.5 \mathrm{~cm} \text {. New wood } 200 \mathrm{~cm} \text {., } \\
& 5 \text { vessels at } \mathrm{I} 34 \mathrm{~cm} \text {., } \\
& \text { also one in proto- } \\
& \text { xylem at } 170 \mathrm{~cm} \text {. } \\
& \text { (exceptional) } \\
& 3 \text { rd yr's. wood } 33 \mathrm{~cm} ., 3 \text { vessels at } \\
& 25 \mathrm{~cm} \text {. } \\
& 102.5,5 \text { vessels at } \\
& 70 \mathrm{~cm} \text {. } \\
& 240 \mathrm{~cm} \text {., } 60 \text { vessels } \\
& \text { at } 95 \mathrm{~cm} \text {. }
\end{aligned}
$$

Diameter of

largest vessel.

-I 3 I $\mathrm{mm}$.

Average

Diameter

of vessels.

.IOI $\mathrm{mm}$.

.IO4 mm.

$.065 \mathrm{~mm}$.

. I3 $\mathrm{mm}$.

$.09 \mathrm{~mm}$.

Average no. of vessels at tip ${ }^{1}$ (2I per sq. mm.), I $33^{6}$

3 yrs. $\quad 6 \mathrm{~cm}$.

$$
\begin{aligned}
& \text { In new wood, } 213 \mathrm{~cm} \text {. (2 vessels), } \\
& \text { one in spring } 8 \text { vessels at } 125 \mathrm{~cm} \text {. } \\
& \text { and one in }
\end{aligned}
$$
autumn wood

Average no. of vessels at tip ( 30 per sq. mm.), I 500

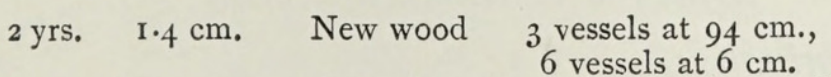

$.08 \mathrm{~mm}$.

$.05 \mathrm{~mm}$.

Average no. of vessels at tip ( $3^{8}$ per sq. mm.), 665

\section{3 yrs. 2.I cm. New wood II $5 \mathrm{~cm} ., 3^{8}$ vessels} at $28 \mathrm{~cm}$.

$.1 \mathrm{~mm}$. $.07 \mathrm{~mm}$. Average no. of vessels at tip ( 26 per sq. mm.), 735

2 yrs. $\quad 1 \cdot 3 \mathrm{~cm}$.

I $9 \mathrm{~cm}$., I 8 vessels at $37 \mathrm{~cm}$.

. I $\mathrm{mm}$. $.06 \mathrm{~mm}$. 
Acacia mollissima (continued):--

(f) Branch of same Length $\mathrm{I} \cdot 25 \mathrm{~m}$.

$$
\text { Age. } \begin{gathered}
\text { Diameter } \\
\text { at base. }
\end{gathered} \quad \begin{gathered}
\text { Position of } \\
\text { longest vessel. }
\end{gathered} \quad \begin{gathered}
\text { Length of } \\
\text { longest vessel. }
\end{gathered}
$$

2 yrs. $\quad 1.6 \mathrm{~cm}$.

New wood

I 2 I cm., I 7 vessels

at $74 \mathrm{~cm}$.

$\begin{array}{cc}\text { Diameter of } & \begin{array}{c}\text { Average } \\ \text { Diameter } \\ \text { largest vessel. }\end{array} \\ \text { of vessels. }\end{array}$ $.098 \mathrm{~mm}$.

$.07 \mathrm{~mm}$.

Acacia Lophantha:

Branch

I yr. I $\quad$ cm.

$40 \mathrm{~cm} ., 29$ vessels

$.12 \mathrm{~mm}$.

$.08 \mathrm{~mm}$

Average no. of vessels at base (13 per sq. mm.), I02I

Very similar results were given by young trees of Eucalyptus, except that there was an even more marked difference in the appearance of the wood from the trunk and branches, the vessels of the latter being much smaller in diameter and much more numerous per sq. centimetre. The fact that one or two vessels out of several thousand may run nearly the whole length of the tree, and only a small percentage one-third to half the length of the tree, the great majority being very much shorter than this, is somewhat suggestive. It may be that these few very long vessels are specially adapted to convey continuous columns of water with ease and rapidity, but that since a single bubble or plug of gum may throw the whole tube out of action more or less completely, the plant prefers to rely for everyday use on the more numerous much shorter vessels, where the blocking of single vessels is less serious. On the other hand, the formation of these single vessels of great length may be more or less the result of accident, or at least not a fact of any special functional significance.

\section{Mercury Method.}

\section{Eucalyptus maculata var. citriodora:}

(a) Branch

Age. Diameter Position of

\section{Length of
longest vessel.}

6-8 yrs. $2.1 \mathrm{~cm}$. Newest wood

Branch

6 yrs. $2.5 \mathrm{~cm}$.

New wood

Average no. of vessels in stem, 9,500

25 at $96 \mathrm{~cm}$.

I $9 \mathrm{~cm}$., 19 vessels at $78 \mathrm{~cm}$.

Branch

$105.5 \mathrm{~cm} ., 22$ ves-
Average no. of vessels in stem, 8,835

II. Eucalyptus viminalis:

Forked tree.

Height $2.5 \mathrm{I} \mathrm{m}$.

$\begin{array}{llll}\text { Fork A. } & 6 \text { yrs. } & 4.5 \mathrm{~cm} . & \text { In new wood } \\ \text { Fork B. } & 6 \text { yrs. } & 4.4 \mathrm{~cm} . & \text { In new wood } \\ \text { ranch of same } & 3 \text { yrs. } & \begin{array}{r}\text { I. } 4 \mathrm{~cm} . \\ \text { Root, }\end{array} & \text { In new wood } \\ \text { Root and } & 6 \text { yrs. } & \begin{array}{r}2.5 \mathrm{~cm} . \\ \text { hypocotyl }\end{array} \\ & & \begin{array}{c}\text { Hypo., } \\ \text { I } 2 \mathrm{~cm} .\end{array}\end{array}$
sels at $85 \mathrm{~cm}$.

\section{Diameter of} largest vessel.

. $145 \mathrm{~mm}$. $.076 \mathrm{~mm}$.

$.084 \mathrm{~mm}$.

Average

Diameter of vessels.

$.093 \mathrm{~mm}$. $.054 \mathrm{~mm}$. $.065 \mathrm{~mm}$.

I $98 \mathrm{~cm}$., 9 vessels at $147 \mathrm{~cm}$.

I $99.3 \mathrm{~cm} ., 4$ vessels at $195 \mathrm{~cm}$.

5 vessels at $90 \mathrm{~cm}$.

I' 7 vessels at $62 \mathrm{~cm}$.

. I $8 \mathrm{~mm}$.

$.082 \mathrm{~mm}$

Judging from its position, the longest vessel probably extended from root through main axis. Length about $316 \mathrm{~cm}$. 
Eucalyptus globosa:

(a) Full tree, height $8 \mathrm{yrs} . \quad 8.9 \mathrm{~cm} . ; \quad 7$ th and 8 th
$6.7 \mathrm{~m}$. Mercury $6.7 \mathrm{~m}$. Mercury
applied at tip of trunk.

diam. at years' cut tip, $2 \mathrm{~cm}$.

Average no. of vessels in stem at tip, 8 per sq. mm. ; at base, 9 per sq. mm.

(b) Branch of same 3yrs. I cm. New wood 87 cm., ro vessels $\quad .069 \mathrm{~mm}$. $.053 \mathrm{~mm}$.

Average no. of vessels in stem, 60 per sq. $\mathrm{mm}$.

A few data are appended upon the dimensions of the vessels in the Oleander, Ficus, Deeringia, and Tecoma, but in none of these did the vessels attain anything like the length shown by single vessels of Eucalyptus and Acacia. Experiments have still to be performed on adult trees of Eucalyptus 100 feet high or more, but these have been postponed for the present, since the work must be done on the spot where the trees grow and entails considerable expense.

Nerium Oleander:

\section{Mercury Method.}

\begin{tabular}{|c|c|c|c|c|c|}
\hline Age. & $\begin{array}{l}\text { Diameter } \\
\text { at base. }\end{array}$ & $\begin{array}{c}\text { Position of } \\
\text { longest vessel. }\end{array}$ & $\begin{array}{l}\text { Length of } \\
\text { longest vessel. }\end{array}$ & $\begin{array}{l}\text { Diameter of } \\
\text { largest vessel. }\end{array}$ & $\begin{array}{l}\text { Average } \\
\text { Diameter } \\
\text { of vessels. }\end{array}$ \\
\hline 2 yrs. & $1 \mathrm{~cm}$. & & $5^{2} \mathrm{~cm}$. & $.057 \mathrm{~mm}$ & $.03^{8} \mathrm{~mm}$. \\
\hline 6 yrs. & Average no & of vessels in $\mathrm{s}$ & $\begin{array}{l}75.5 \mathrm{~cm} \text {. (shaded, } \\
\text { therefore less active } \\
\text { transpiration), } 26 \\
\text { vessels at } 39 \mathrm{~cm} \text {. } \\
\mathrm{em}, 108,500\end{array}$ & $.035 \mathrm{~mm}$. & $.021 \mathrm{~mm}$. \\
\hline & $\begin{array}{l}.9 \mathrm{~cm} . \\
\text { Average } \mathrm{n}\end{array}$ & $\begin{array}{l}\text { 3rd yr's. wood } \\
\text { of vessels in st }\end{array}$ & $\begin{array}{l}74 \mathrm{~cm} ., \text { I } 7 \text { vessels } \\
\text { at } 40 \mathrm{~cm} \text {. } \\
\mathrm{n}, 61,236\end{array}$ & $.046 \mathrm{~mm}$. & $.026 \mathrm{~mm}$. \\
\hline
\end{tabular}

As far as these results go they show that the length of the vessels is more affected by the age of the stem than by the activity of transpiration, whereas the degree of functional use appears to affect their diameters to a marked extent, active transpiration favouring an increase in diameter.

(a)

(b)

(c)

\section{Mercury Method.}

Ficus elastica :

Age. Diameter $\begin{gathered}\text { Position of } \\ \text { at base. }\end{gathered}$ longest vessel. $\quad \begin{gathered}\text { Length of } \\ \text { longest vessel. }\end{gathered}$

Branch Io yrs. $\quad 1.8 \mathrm{~cm}$.

Branch

2 yrs. I $\mathrm{cm}$.

New wood

New wood

$47 \mathrm{~cm}$., 20 vessels at $38 \mathrm{~cm}$.

$53 \mathrm{~cm}$., 25 vessels at $32 \mathrm{~cm}$.

Deeringia altissima :

Branch 3 yrs

Branch

3 yrs

Tecoma:

Branch

3 yrs. $\quad 6 \mathrm{~cm}$.
$.7 \mathrm{~cm}$. New wood $74 \mathrm{~cm} ., 12$ vessels at $43 \mathrm{~cm}$.

$97 \mathrm{~cm}$., I5 vessels at $69 \mathrm{~cm}$.

$4^{8 \mathrm{~cm}}$., 8 vessels at $28 \mathrm{~cm}$.

$\begin{array}{cc}\text { Diameter of } & \begin{array}{c}\text { Average } \\ \text { Diameter } \\ \text { largest vessel. }\end{array} \\ \text { of vessels. } \\ . \mathrm{I} 37 \mathrm{~mm} . & .085 \mathrm{~mm} . \\ .092 \mathrm{~mm} . & .072 \mathrm{~mm} .\end{array}$

$.047 \mathrm{~mm}$. $\quad .032 \mathrm{~mm}$.

$.059 \mathrm{~mm}$. $\quad .004 \mathrm{~mm}$.

$.076 \mathrm{~mm} . \quad .05 \mathrm{~mm}$. 
The Resistance to Flow under Varying Pressures.

The resistance to flow naturally depends upon a variety of factors, and from the data already given as to the dimensions of the vessels, it is

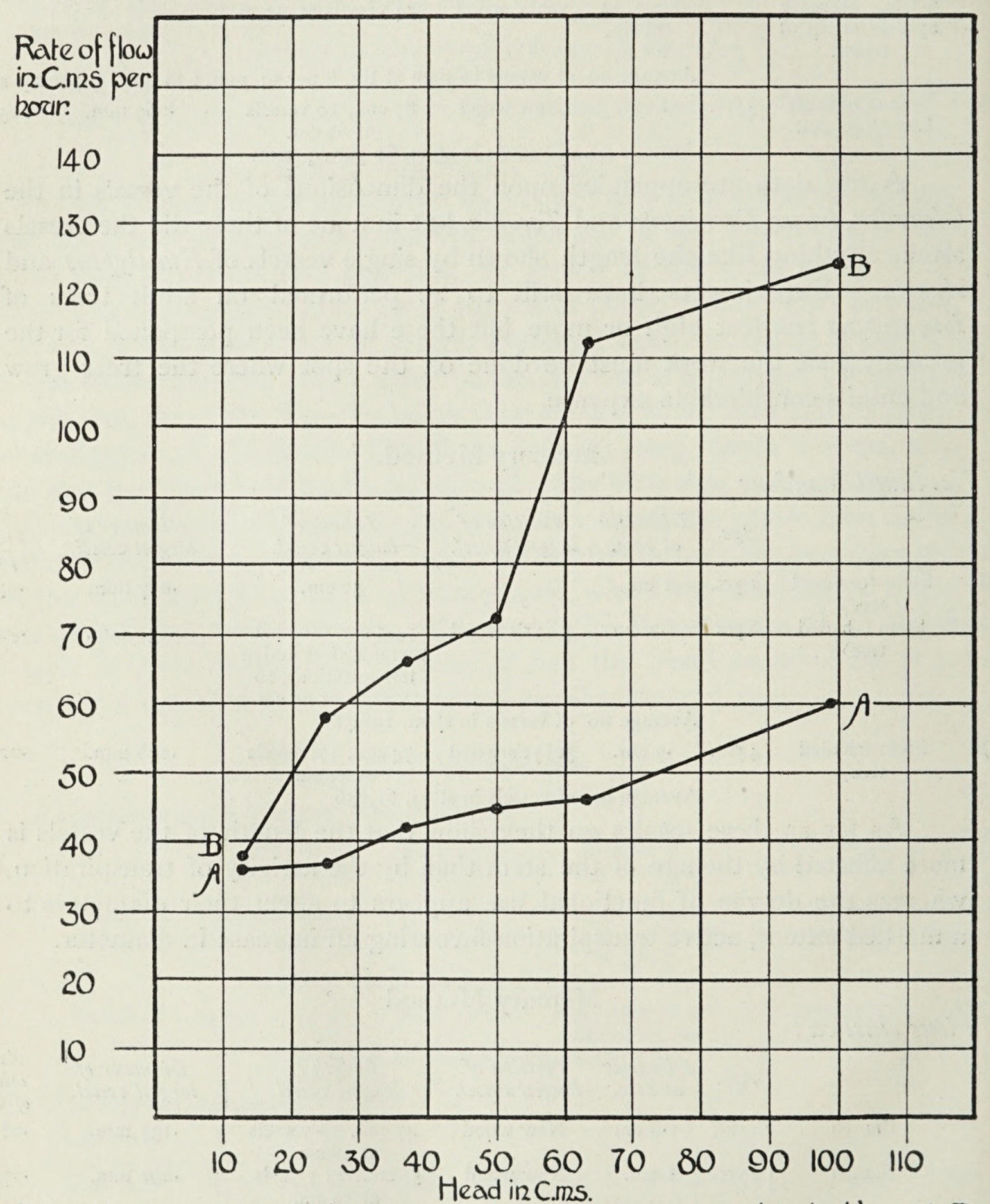

Rate of flow under varying heads in non-saturated- $A$, and in saturated branch-B. Figare 3 . Eucalyptus viminalis.

evident that, other things being equal, it will be more rapid in large branches and main stems than in equal lengths of the smaller branches under similar heads. In the following experiments the branches for each 
set of experiments were all of equal length, and as far as possible of equal diameter and similar shape. In each double series the first set, A, consists of branches taken directly from actively transpiring trees: the second set, B, consists of branches saturated as far as possible with water. The branches were laid horizontally and eosin driven through under varying pressures, noting the time of flow in each case.

\section{Eucalyptus viminalis.}

A.

Length of stem $50 \mathrm{~cm}$.

Heads in cm. of water.

I. $12.5 \mathrm{~cm}$. ( $\frac{1}{4}$ head)

2. $25 \mathrm{~cm}$. ( $\frac{1}{2}$ head)

3. $37.5 \mathrm{~cm}$. ( $\frac{3}{4}$ head)

4. $50 \mathrm{~cm}$. (I head)

5. $63 \mathrm{~cm}$. (I $\frac{1}{4}$ heads)

6. $100 \mathrm{~cm}$. (2 heads)

B.

Heads in cm. of water.
I. $12.5 \mathrm{~cm}$.
2. $25 \mathrm{~cm}$.
3. $37.5 \mathrm{~cm}$.
4. $50 \mathrm{~cm}$.
5. $63 \mathrm{~cm}$.
6. $100 \mathrm{~cm}$.

Rate of flow per howr.

$36 \mathrm{~cm}$.

$37 \mathrm{~cm}$.

$4^{2} \mathrm{~cm}$.

$45 \mathrm{~cm}$.

$46 \mathrm{~cm}$.

$60 \mathrm{~cm}$. (older branch)

Rate of flow per hour.

$$
\begin{aligned}
& 38 \mathrm{~cm} \text {. } \\
& 58 \mathrm{~cm} \text {. } \\
& 66 \mathrm{~cm} \text {. } \\
& 72 \mathrm{~cm} \text {. } \\
& \text { I } 2 \mathrm{~cm} \text {. } \\
& \text { I } 24 \mathrm{~cm} \text {. }
\end{aligned}
$$

Acacia mollissima.

A.

Length of stem $50 \mathrm{~cm}$. Temp. $25^{\circ} \mathrm{C}$.

Head's in $\mathrm{cm}$. of water.
I. $12.5 \mathrm{~cm}$.
2. $25 \mathrm{~cm}$.
3. $37.5 \mathrm{~cm}$.
4. $50 \mathrm{~cm}$.
5. $63 \mathrm{~cm}$.
6. $75 \mathrm{~cm}$.
7. $100 \mathrm{~cm}$.

B.

Heads in $\mathrm{cm}$. of water.
I. $12.5 \mathrm{~cm}$.
2. $25 \mathrm{~cm}$.
3. $37.5 \mathrm{~cm}$.
4. $50 \mathrm{~cm}$.
5. $63 \mathrm{~cm}$.
6. $75 \mathrm{~cm}$.
7. $100 \mathrm{~cm}$.

Rate of flow per hour. $28 \mathrm{~cm}$.

$59 \mathrm{~cm}$.

$68 \mathrm{~cm}$.

$80 \mathrm{~cm}$.

$88 \mathrm{~cm}$.

$99 \mathrm{~cm}$. $187 \mathrm{~cm}$.

Rate of flow per howr.

$32 \mathrm{~cm}$.
$64 \mathrm{~cm}$.
I $8 \mathrm{~cm}$.
I $72 \mathrm{~cm}$.
$375 \mathrm{~cm}$.
$388 \mathrm{~cm}$.
$460 \mathrm{~cm}$.

These results fluctuate considerably, but so also does the material, and it is quite useless by careful selection to obtain consistent results 
which do not represent any such consistency in the plant. The resistance to flow in transpiring plants varies in fact along the path of the transpiration current, and all we need to determine is the maximal total resistance and the approximate limits of variation. In any case the results suffice to show that the presence of air not only lowers the conductivity but causes increasing heads to produce less and less of the expected flow. The discrepancy may become remarkable. Thus in the following series of experiments with Eucalyptus amygdalina the segments I-7 were taken

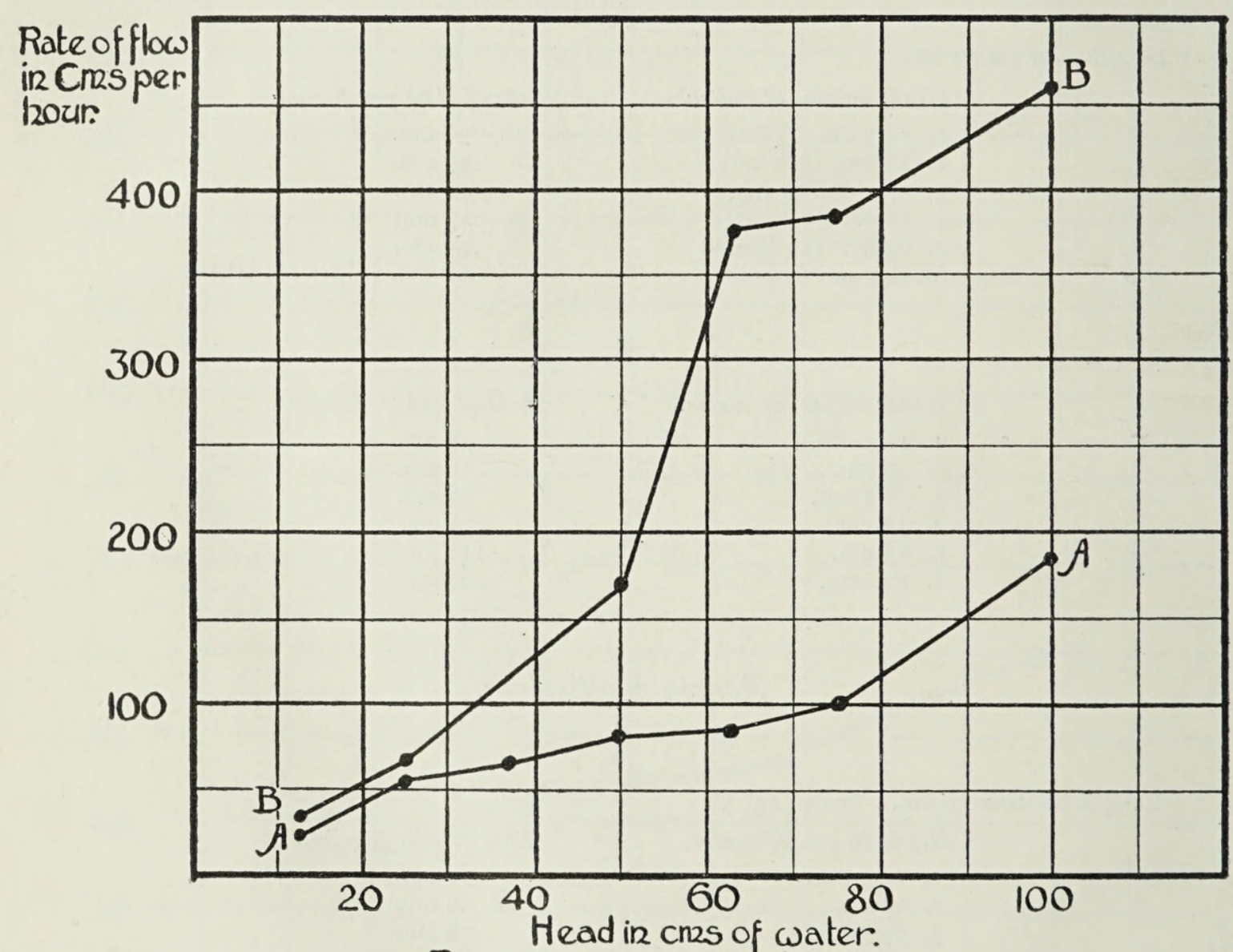

Figure 4. Acacia mollissima.

from two slender transpiring shoots with short and narrow vessels, whereas No. 8 was a large main stem of a tree and was saturated with water. Even in this case, in which the resistance to flow is probably nearly minimal, it requires a head of twice the length of stem to produce a rate of flow of 3 metres an hour, which is a fair average rate for the active transpiration current in Eucalyptus, and to produce the maximal rate observed of 12 metres per hour would need a correspondingly increased head. 


\section{Eucalyptus amygdalina.}

Length of stem $5 \circ \mathrm{cm}$. Temperature $20^{\circ}$.
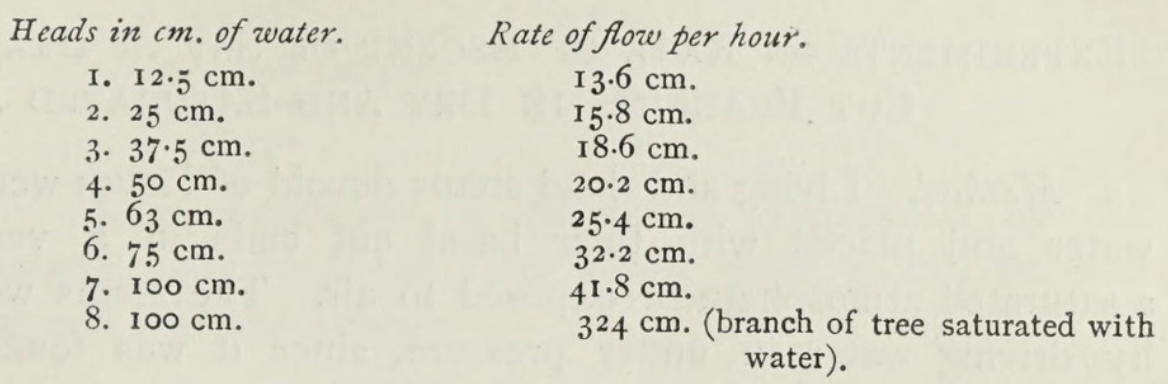

With exceptionally favourable material of Acacia mollissima, Miss Rees obtained a maximal rate of flow of $1,080 \mathrm{~cm}$. per hour for a $50 \mathrm{~cm}$. length of stem under a head of $50 \mathrm{~cm}$. of water at $25^{\circ} \mathrm{C}$. Assuming that this was

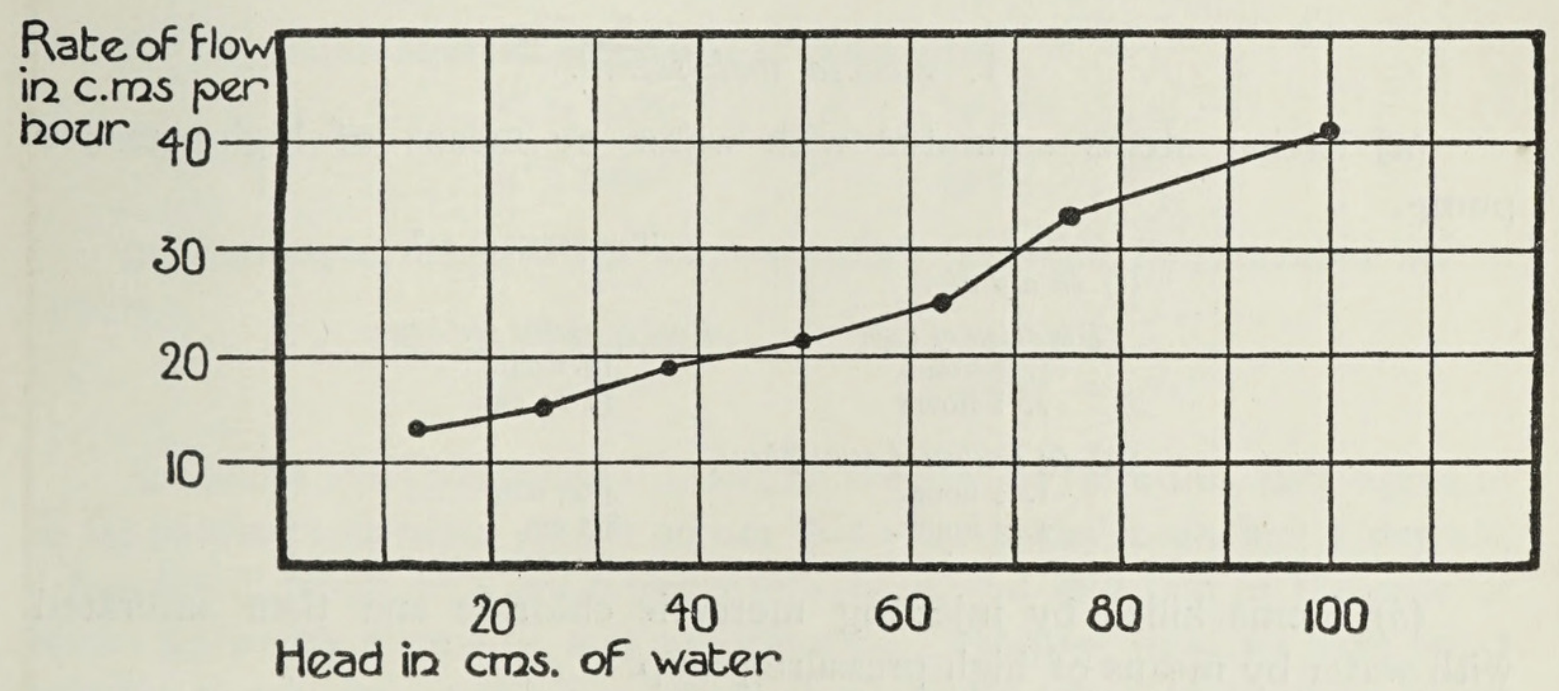

Fig 5 Eucalyptus amygdalina

through an open vessel of $0.01 \mathrm{~cm}$. diameter, the rate of flow would, according to a theoretical calculation from Poisseuille's formula, have been thirty times greater, and in a vessel of $0.05 \mathrm{~cm}$. diameter seven times greater. Similarly, with a head of $100 \mathrm{~cm}$., the rate of flow was only $\mathbf{I}, 560 \mathrm{~cm}$. per hour, or less than one-thirtieth the theoretical value. The difference is due to the facts that the vessels are not perfectly circular, that their walls are not smooth, that they are longer than the stem bearing them, and that at every sharp bend with a high rate of flow, eddy currents will form which increase the resistance to flow, and finally that whenever one vessel is conducting under pressure more rapidly than neighbouring ones, lateral exudation through the permeable walls will tend to level up, or rather level down, the rate of flow more or less to the average one for 
the whole wood cylinder. The influence of the eddy currents and lateral exudation will increase as the pressure and resultant velocity of flow increase.

\section{Experiments on Rate of Ascent of Sap in Dead and Living Cut Branches in Dry and Saturated Air.}

Method. Living and dead stems devoid of leaves were saturated with water and placed with their basal cut ends in a vessel of eosin in a saturated atmosphere or exposed to air. The stems were all saturated by driving water in under pressure, since it was found impossible to saturate them fully by drawing in water by means of a suction pump. In injecting the stems no blocking occurred if a fresh surface was cut under water before attaching to the pump and distilled or filtered water was used. After a certain length of time the height to which the eosin had ascended in the different stems was noted.

\section{Acacia mollissima.}

(a) Living stems saturated with water by means of high-pressure pump.

(i) In dry air.

$\begin{array}{cc}\text { Duration of exp. } & \text { Rate of ascent per hour. } \\ \text { I. } 2 \text { hours } & \text { I } 4.1 \mathrm{~cm} \text {. } \\ \text { 2. } 2 \text { hours } & \mathrm{II} \cdot 25 \mathrm{~cm} .\end{array}$

(ii) In saturated atmosphere.
I. 2 hours
2. 2 hours.
$4.65 \mathrm{~cm}$.
$8.5 \mathrm{~cm}$

(b) Stems killed by injecting mercuric chloride and then saturated with water by means of high-pressure pump.
(i) In dry air.
1. 2 hours
2. 2 hours
$5 \mathrm{~cm}$.
(ii) In saturated atmosphere.
I. 2 hours
2. 2 hours
$5 \mathrm{~cm}$.
I. $5 \mathrm{~cm}$.
$3.5 \mathrm{~cm}$.

\section{Eucalyptus amygdalina.}

(a) Living stems saturated with water by means of high-pressure pump.

(i) In dry air.

Duration of exp.

I. I hour

2. I hour

Temperature $2 \mathbf{1}^{\circ}$.

(ii) In saturated at mosphere,

I. I hour

2. I hour

Rate of ascent per hour.

$27 \mathrm{~cm}$.

I $5 \mathrm{~cm}$.

I $2 \mathrm{~cm}$.

I $5 \mathrm{~cm}$. 
(b) Stems killed by injecting with mercuric chloride and then saturated with water by means of high-pressure pump.

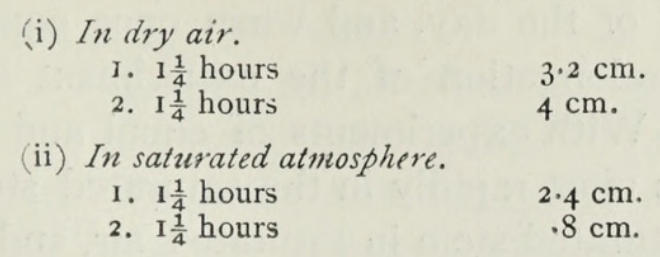

The rate of ascent decreases in geometric progression as the experiment progresses and the liquid rises in the stem, as can be seen from the following and preceding data :-

\section{Nerium Oleander.}

(a) Saturated stem in dry atmosphere:

$\begin{array}{cc}\text { Duration of exp. } & \text { Rate of ascent per hour. } \\ \text { I. } 3 \text { hours } & 7.6 \mathrm{~cm} . \\ \text { 2. } 7 \text { hours } & 4.3 \mathrm{~cm} .\end{array}$

(b) Saturated stem in saturated atmosphere:

$\begin{array}{ll}\text { I. } 24 \text { hours } & .42 \mathrm{~cm} . \\ \text { 2. } 4 \text { hours } & \text { I. } \mathrm{cm} . \\ \text { 3. } 4 \text { hours } & 1.2 \mathrm{~cm} .\end{array}$

(c) Saturated stem killed with mercuric chloride in saturated atmosphere:

$$
\begin{array}{ll}
\text { I. } 4 \text { hours } & -4 \mathrm{~cm} \text {. } \\
\text { 2. } 24 \text { hours } & -3 \mathrm{~cm} \text {. }
\end{array}
$$

Although the results show a certain amount of variation, they agree in so far as the most rapid ascent occurs in cut saturated branches in dry air, a less rapid ascent in a saturated atmosphere, and still less in the case of stems killed by means of mercury chloride. At first sight we have what seems a conclusive proof of an upward pumping action exerted by living stems, for it is difficult to see how any ascent could be produced by capillarity and evaporation in a saturated stem in a saturated atmosphere. The action does not seem, however, to be appreciably influenced by whether the stem is in the normal or inverted position provided both ends are equal in diameter, and further the fact that any rise at all is shown in a dead saturated stem in a saturated atmosphere is sufficient proof that the ascent is physical in origin. Its exact nature needs, however, further investigation. An ascent of liquid in a saturated stem in a saturated atmosphere at a rate of $12-15 \mathrm{~cm}$. in an hour is too rapid to be explained by ordinary diffusion or imbibition.

The rate of ascent decreases in geometric progression as the experiment progresses and the sap rises up the cut stem. Exactly the same applies to the capillary ascent in a glass tube, for, as the column rises, less and less force is available to overcome the gravitational acceleration and 
frictional resistance of the ascending stream. In the case of the Oleander the maximal height reached in a saturated atmosphere (Io $\mathrm{cm}$.) was attained before the end of the day, and when once equilibrium has been reached, any further prolongation of the experiment simply lowers the apparent rate of flow. With experiments of equal and not too prolonged duration the liquid rises most rapidly in the saturated stem in dry air, less rapidly in the living saturated stem in saturated air, and still more slowly in the stem killed by mercuric chloride.

Suggestive as these results are, they must only for the present be taken as indicating a possible mode of demonstrating the existence of a pumping action in the wood of transpiring trees.

If such a pumping action exists we should expect to find the sap ascending in the stem of a tree after the leaves had been removed, especially if the tree was previously short of water.

Accordingly the whole of the branches and leaves were removed from a tree of Araucaria excelsa $8 \frac{1}{2}$ metres high. After attaching the trunk to scaffolding it was sawn across at the base under a jet of water, trimmed under water and lowered into a drum of eosin solution. After two months, no eosin having appeared at the top, it was sawn up and examined.

The eosin had risen on one side in the second and fourth rings to a height of $\mathrm{I}_{34} \mathrm{~cm}$. The wood was uniformly tinged only below $50 \mathrm{~cm}$., but was moist and living at all points. The experiment was begun near the close of summer after a two months' spell of dry weather, and yet the rate of ascent barely exceeded $2 \mathrm{~cm}$. per day on the average for the whole time. This fact negatives the conclusions that might have been drawn from short lengths of stems, but leaves it still an open question as to whether or no a pumping action may exist but only act under the stimulus of demand, and be of such character as to allow a moderate suction of nearly equal intensity at all points to extend to the ground, each region in the path of the transpiring current maintaining its water in a labile condition so as to neither appreciably add to nor diminish the suction exerted by the leaves, which is transmitted by cohering columns of water as far as their tensile strength will allow and as far as they exist.

\section{Summary.}

The rate of evaporation per sq. metre of leaf-surface from cut branches, whether placed in water or not, is always less than from a plant rooted in the soil, under otherwise similar conditions.

When the air is hot and dry the evaporation from a free surface of water undergoes an enormous increase, but that from a living plant undergoes a regulatory decrease, and may be only one-sixth as active as the former. Under optimal conditions a rooted plant of Eucalyptus corynocalyx 
may lose 396 grams of water per sq. metre of transpiring leaf-surface per hour, whereas the maximum rate for Dracaena Draco was 17.6 grams.

Cut trees always absorb water at a less rate than rooted ones evaporate it. The maximum rate of ascent of sap noted was I2.3 metres per hour (Eucalyptus viminalis) and 6.5 metres per hour (E. amygdalina), whereas in cut branches of Eucalyptus and in cut trees of Acacia mollissima it rarely exceeds I to 2 metres an hour, and is often less than I metre.

Single vessels may run nearly from end to end of the main trunk in young Eucalyptus and Acacia trees several metres high, but only a very small fraction exceed half the main trunk in length. In the branches the vessels are shorter and narrower, but the sap will usually not pass any more transverse partitions in the wood-vessels than it does in the process of passing from root-hair to wood, and from the wood to the transpiring surface. The existence of a rapid transpiration current appears to favour the development of broad vessels, but not to affect their length.

Branches containing air taken from actively transpiring trees show a much greater resistance to flow than when saturated with water; and with increasing heads the rate of flow does not increase proportionately. To produce the transpiration rate of flow heads of two to ten times the length of stem may be required, but in unblocked fully saturated stems with large long vessels a head of one-fifth the length of stem may be sufficient. During prolonged active transpiration, however, the total resistance to the upward flow of sap in a Eucalyptus tree may amount to a head of two to ten times the height of the tree, which would therefore equal in the tallest trees a maximal pressure lying between 20 and 100 atmospheres.

A coloured liquid will rise slowly in a saturated stem kept in a saturated atmosphere, but a somewhat slower ascent is shown after the stem has been killed, so that the phenomenon is not the result of any vital pumping action, and must be capable of a physical explanation, although in a saturated stem it cannot be due to capillarity or imbibition, and is too rapid to be the result of diffusion.

No appreciable rise of sap took place in a tree deprived of its leaves, but a pumping action may only be excited when the leaves are exerting suction on the water in the wood. 


\section{$2 \mathrm{BHL}$ Biodiversity Heritage Library}

Ewart, Alfred J. and Rees, Bertha. 1910. "Transpiration and the ascent of water in trees under Australian conditions." Annals of botany 24, 85-105. https://doi.org/10.1093/oxfordjournals.aob.a089265.

View This Item Online: https://www.biodiversitylibrary.org/item/262605

DOI: https://doi.org/10.1093/oxfordjournals.aob.a089265

Permalink: https://www.biodiversitylibrary.org/partpdf/319761

\section{Holding Institution}

New York Botanical Garden, LuEsther T. Mertz Library

\section{Sponsored by}

BHL-SIL-FEDLINK

\section{Copyright \& Reuse}

Copyright Status: Public domain. The BHL considers that this work is no longer under copyright protection.

This document was created from content at the Biodiversity Heritage Library, the world's largest open access digital library for biodiversity literature and archives. Visit BHL at https://www.biodiversitylibrary.org. 